Original Research Paper

\title{
Supplementation of Lysine Essential Amino Acids in Commercial Feed to Increase Eicosapentaenoic Acid (EPA) and Docosahexaenoic Acid (DHA) in Catfish (Pangasius sp.) Fillet
}

\author{
Muhammad Taufiq Shidqi ${ }^{1 *}$, Agustono ${ }^{2}$, Mirni Lamid ${ }^{2,3}$, Putu Angga Wiradana ${ }^{4}$ \\ ${ }^{1}$ Master Program of Biotechnology of Fisheries and Marine, Faculty of Fisheries and Marine, \\ Universitas Airlangga, Kampus C, Jalan Mulyorejo, Surabaya (60115), East Java, Indonesia \\ ${ }^{2}$ Department of Fish Health Management and Aquaculture, Faculty of Fisheries and Marine, \\ Universitas Airlangga, Kampus C, Jalan Mulyorejo, Surabaya (60115), East Java, Indonesia \\ ${ }^{3}$ Department of Animal Husbandry, Faculty of Fisheries and Marine, Universitas Airlangga, Kampus \\ C, Jalan Mulyorejo, Surabaya (60115), East Java, Indonesia \\ ${ }^{4}$ Study Program of Biology, Faculty of Health, Science and Technology, Universitas Dhyana Pura, \\ North Kuta, Badung Regency (80351), Bali Province, Indonesia
}

\begin{abstract}
Article History
Received : September $01^{\text {th }}, 2021$

Revised : September $15^{\text {th }}, 2021$

Accepted : September 30 ${ }^{\text {th }}, 2021$

Published : October $13^{\text {th }}, 2021$

*Corresponding Author:

Muhammad Taufiq Shidqi,

Master Program of Biotechnology of Fisheries and Marine, Faculty of Fisheries and Marine,

Universitas Airlangga, Kampus

C, Jalan Mulyorejo, Surabaya (60115), East Java, Indonesia Email: shidqit@gmail.com
\end{abstract}

\begin{abstract}
The purpose of this study is to see how adding the amino acid lysine to commercial feed affects the amount of EPA and DHA in catfish (Pangasius sp.) flesh. This study is an experimental study with a totally randomized design that includes four treatments and five replications. $\mathrm{P} 0$ (100\% commercial feed +1.2 percent amino acid lysine), P2 (100\% commercial feed +2.2 percent amino acid lysine), and P3 (100\% commercial feed +3.2 percent amino acid lysine) were the treatments. The parameters observed were EPA and DHA in catfish meat. Data analysis used ANOVA and continued with the DUNCAN test ( $\mathrm{p} 0.05)$. The results showed that the addition of the amino acid lysine to commercial feed for 30 days of maintenance was able to increase the EPA and DHA content in catfish meat. The highest EPA content was obtained by treatment P1 (1.2\% amino acid lysine), which was $0.597 \%$, while the highest DHA content was obtained by treatment P2 (2.2\% amino acid lysine), which was $0.747 \%$. Our findings demonstrate that adding the amino acid lysine to the diet can result in nutrient-rich catfish flesh. However, studies on the influence of lysine amino acid on the growth rate, survival rate, and cholesterol ratio in catfish flesh are predicted to enhance the productivity of this very nutritious fish.
\end{abstract}

Keywords: Amino acid, aquaculture sector, human health, fillet quality, catfish

\section{Introduction}

Natural fisheries and marine resources abundance in Indonesian seas. Catfish (Pangasius sp.) is one of the possible fisheries resources to be farmed in Indonesia (Tran et al., 2017). Catfish products are claimed to offer high nutritional value for human nutrition, including protein $(60 \%)$, calcium $(8 \%)$, and phosphorus (4.2\%) (Dale, 2001). Furthermore, catfish meat is thought to be healthier than animal meat due to its lower cholesterol content (Rario, 2015). According to a study released by the Ministry of Maritime Affairs and Fisheries (KKP, 2010), national catfish production grew substantially in 2010 to 147,890 tons. Catfish output in Indonesia increased steadily until it reached 229,267 tons in 2011. Given this, Indonesia has the ability to contribute 16.11 percent of global catfish output (FAO, 2013) and as a commodity with promising possibilities for domestic cultivation.

\section{Catfish (Pangasius sp.) have great}


qualities such as being easy to breed (Syukur et al., 2014), growing quickly (Lestari et al., 2020), having resistant to environmental changes (Nirmala et al., 2007), and having high meat quality (Girsang et al., 2020). However, the low concentration of omega- 3 fatty acids in freshwater fish (particularly catfish) as compared to marine fish remains an issue for freshwater fish farmers to this day. As a result, it is critical to enhance the nutritional quality of catfish, which is an essential source of EPA and DHA and capable of generating botulism. As a reason, it is vital to enhance the nutritional quality of catfish as a key source of EPA and DHA and capable of generating substantial amounts of both types of fatty acids (Alagawany et al., 2019; Scollan et al., 2017; Stoneham et al., 2018).

The nutritional requirements of fish feed are the most essential factors that may be employed to improve the quality and consistency of fish flesh (Kwasek et al., 2020). The addition of feed additives to fish feed can boost growth, immunity, and nutritional quality of fish flesh (Lakshmi et al., 2019). Lysine is an important amino acid that is commonly utilized as a feed supplement in animals such as pigs and poultry (Brautaset \& Ellingsen, 2011). The addition of lysine to commercial feed is predicted to result in the formation of carnitine, which then plays a function in the fat metabolism process to generate energy (Borum, 2020). Carnitine can also help with the transport of long-chain fatty acids into the mitochondria, stimulate development, guard against ammonia toxicity, and boost the body's resistance to harsh temperature fluctuations (Longo et al., 2016).

According to Xie et al., (2012), adding 1.515 percent of the feed quantity to lysine can improve the growth of white shrimp (Litopenaeus vannamei). Khalida, Agustono, \& Paramita, (2017) found that adding 1.2 percent of the total diet to the essential amino acid lysine increased the growth rate, feed efficiency, and survival of freshwater pomfret (Colossoma macropomum). Omega-3 is a necessary unsaturated fatty acid for the body, and it is especially important for those who have excessive cholesterol (Gammone et al., 2019). Fatty acids that are unsaturated The most common omega-3 fatty acids found in fish oil are EPA and DHA. EPA and DHA fatty acids have the ability to lower cholesterol levels by blocking LDL production and promoting HDL synthesis (Pizzini et al., 2017).

Based on this, the main objective of this research is to analyze the influence of adding the important amino acid lysine to commercial feed on the levels of EPA and DHA in catfish flesh (Pangasius sp.).

\section{Materials and methods}

\section{Study area}

The Wet Laboratory, Faculty of Fisheries and Marine, Universitas Airlangga, was used to maintain, acclimate, and provide amino acid lysine therapy to catfish. The Veterinary Testing and Feed Analysis Unit, Faculty of Veterinary Medicine, Universitas Airlangga, performed proximate analysis on commercial feed and commercial lysine material. The Testing Service Unit (ULP), Faculty of Pharmacy, Universitas Airlangga, performed fatty acid analysis on fish feed and catfish flesh.

\section{Tools and materials}

The tools used in the study included 20 aquariums (Gex Glassterior Series, Jpn) with a size of $30 \mathrm{~cm} \times 30 \mathrm{~cm} \times 40 \mathrm{~cm}$, aerator air pump LP-40, aeration hose (Puso, Id), suction hose (Aquaries, Id), 20 aeration stones (Yamano, Jpn), black plastic polybag, litmus paper (Merck, USA) to measure $\mathrm{pH}$, thermometer (Resun, China), DO meter (Hanna Instrument, Id), ammonia test kit (Hanna Instrument, Id), digital scales (SigmaAldrich, USA), tubular fiber for water reservoirs, rulers or calipers, stationery, bottles to collect feces and leftover feed, basins, buckets, and slides.

The test animals used in this study were catfish with a size of 6-8 $\mathrm{cm} / \mathrm{head}$ obtained from fish farmers in Lamongan Regency, East Java. The catfish used were 200 fish. The feed used in the study was commercial feed in the form of pellets. The essential amino acid lysine and tapioca starch as a binder.

\section{Research procedure}

\section{Preparation}


An aquarium (Gex Glassterior Series, Jpn), aeration hose (Puso, Id), aeration stone (Yamano, Jpn), and tubular fiber tubs for reservoir water were utilized in the study. The aquarium is cleaned with soap and rinsed with running water until clean before being treated with a chlorine disinfectant for 24 hours. The chlorine-containing water is removed the next day and washed with clean water before being sun-dried to minimize the chlorine odor.

The preparation of freshwater for maintenance begins with the installation of an aerator to enhance dissolved oxygen levels and the deposition of the current suspension in maintenance. The aquarium is cleansed with new water that has been deposited with each aerator installation as an oxygen supply.

\section{Test animal}

Catfish are select first, then memories are supplied. The selection criteria include size uniformity, completeness of body organs, and fish health. Catfish are kept at a length of 7-8 $\mathrm{cm}$ per tail. Catfish were acclimatized for 5 days prior to stocking. Acclimatization focuses on improving catfish adaptation to the aquatic environment (P. A. Wiradana et al., 2019). To reduce stress, catfish stocking is done in the morning or evening. Ten fish were kept in each experimental container (Pramudya, 2014).

\section{Preparation of feed ingredients}

Commercial feed in the form of pellets is utilized. The feed utilized is also modified to get the desired formulation. The feed pellets are first ground to make them smaller in size. Milling is intended to aid in the homogeneity of feed by including the amino acid lysine and tapioca flour. The feed that has been milled is next weighed.

Weighing is done meticulously following the established formula. The lysine utilized is powdered lysine. Table 1 presents the findings of the proximate analysis of commercial feed components and the amino acid lysine.

Table 1. Proximate results of commercial feed and amino acid lysine

\begin{tabular}{|c|c|c|c|c|c|c|c|c|c|}
\hline \multirow[t]{2}{*}{ No } & \multirow[t]{2}{*}{ Sample } & \multicolumn{8}{|c|}{ Analysis result (\%) } \\
\hline & & $\begin{array}{c}\text { dry } \\
\text { ingredients }\end{array}$ & Ash & $\begin{array}{l}\text { Crude } \\
\text { protein }\end{array}$ & $\begin{array}{c}\text { Crude } \\
\text { fat }\end{array}$ & $\begin{array}{c}\text { Coarse } \\
\text { fiber }\end{array}$ & Ca & NFE & $\begin{array}{c}\text { ME } \\
\text { (Kcal/kg) }\end{array}$ \\
\hline 1 & $\begin{array}{c}\text { Commercial } \\
\text { feed }\end{array}$ & 91.3125 & 8.7339 & 23.5577 & 5.991 & 5.6859 & 2.5688 & 47.3440 & 2971.49 \\
\hline 2 & $\begin{array}{c}\text { Lysine } \\
\text { amino acid }\end{array}$ & 95.8199 & 0.5890 & 67.5913 & 2.4807 & 0.5853 & 1.3299 & 24.5736 & 3336.79 \\
\hline
\end{tabular}

Note: NFE: Nitrogen-Free Extract; ME: Energy Metabolism.

The next procedure is to combine commercial feed, lysine, and tapioca flour that has been adjusted to the formulation. Water is used in the mixing procedure (20-40 percent). The feed mixture was mixed until it was homogenous. The feed mixture was then cooked for 20 minutes. The steaming procedure is intended to improve the bonding of the floured feed with the amino acid lysine and tapioca flour. The feed combination is then printed on a pellet press machine to match the size of the catfish's mouth opening. The molded feed mixture is subsequently oven-dried at $60^{\circ} \mathrm{C}$ for $12-24$ hours to lower the water content in the feed, allowing for longer feed storage and contamination-free storage (Putu Angga Wiradana et al., 2018). High-Performance Liquid Chromatography (Sigma-Aldrich, USA) was used to evaluate lysine levels in feed at the Integrated Laboratory, Health Polytechnic of the Ministry of Health Surabaya, East Java. Table 2 presents the results of the lysine content measurement in the diet. 
Table 2. Content of commercial feed formulated with the essential amino acid lysine in each treatment

\begin{tabular}{ccc}
\hline No. & Treatments & Analysis results (gr/100 gr) \\
\hline 1 & P0\% & 0.793 \\
2 & P 1.2\% & 1.021 \\
3 & P 2.2\% & 1.137 \\
4 & P 3.2\% & 1.309 \\
\hline
\end{tabular}

\section{Research design}

A Completely Randomized Design (CRD) was performed, with four treatments and five replications $(n=5)$. The treatment performed in this investigation was the addition of different doses of the important amino acid lysine to commercial feed, as well as a control treatment. The treatments in this study consisted of:

- Treatment P0: $100 \%$ commercial feed

- Treatment P1: $100 \%$ commercial feed $+1.2 \%$ lysine $+1 \%$ tapioca flour
- Treatment P2: $100 \%$ commercial feed $+2.2 \%$ lysine $+1 \%$ tapioca flour

- Treatment P3: 100\% commercial feed $+3.2 \%$ lysine $+1 \%$ tapioca flour

The dose was determined based on the findings of a study conducted by Khalida et al., (2017), which reported an increase in the specific growth rate, feed efficiency, and survival rate of pomfret with a $\%$ addition of lysine. Table 3 shows the nutritional content of feed prepared with the amino acid lysine at varied dosages.

Table 3. Composition of the nutritional content of commercial feed formulated with the amino acid lysine with different doses

\begin{tabular}{ccccc}
\hline \multirow{2}{*}{ Feed materials } & \multicolumn{4}{c}{ Treatments (\%) } \\
\cline { 2 - 5 } & P0 & P1 (1.2\%) & P3 (2.2\%) & P4 (3.2\%) \\
\hline Total dry matter & 91.3125 & 93.3574 & 94.3156 & 95.2738 \\
Total ash & 8.7339 & 8.7426 & 8.7484 & 8.7543 \\
Total crude protein & 23.5577 & 24.3860 & 25.0620 & 25.7379 \\
Total crude fat & 5.9910 & 6.0265 & 6.0513 & 6.0761 \\
Total crude fiber & 5.6859 & 5.6987 & 5.7045 & 5.7104
\end{tabular}

Catfish get fed $5 \%$ of their body weight. Feeding occurs three times each day, in the morning at 8:00 a.m. and in the afternoon at 4:00 p.m. Every 7 days, the amount of feed administered was determined. The biomass was estimated by weighing the total catfish population.

Temperature, oxygen content, ammonia, and $\mathrm{pH}$ were used as supporting factors in this investigation. A thermometer was used to measure the temperature, a DO meter was used to measure the oxygen content, an ammonia test kit was used to measure the ammonia, and a universal $\mathrm{pH}$ paper indicator was used to evaluate the $\mathrm{pH}$ of the water. Water quality parameters, temperature, and $\mathrm{pH}$ were measured once a day in the morning and evening, whereas ammonia and DO were measured once a week in the morning and evening.

\section{Data analysis}

The data was analyzed using the SPSS 23.0 software program (IBM, USA) and Analysis of Variance (ANOVA). If there is a difference in treatment, the Duncan distance test is performed with a 5\% confidence level. Tables were created to display the quantitative data. 


\section{Result and Discussion}

\section{Eicosapentaenoic Acid (EPA)}

Based on the assessment findings of the amino acid lysine in catfish (Pangasius sp.) diet, it was discovered that the amount of Eicosapentaenoic Acid (EPA) in catfish meat differed significantly. Table 4 shows the results of a study of the amount of Eicosapentaenoic Acid (EPA) in catfish flesh.

Table 4. Eicosapentaenoic acid (EPA) levels in catfish meat fed with the amino acid lysine at different concentrations in the feed

\begin{tabular}{cc}
\hline Treatments & EPA contents (gram/100gram) \pm SD \\
\hline $\mathrm{P}_{0}(0 \%)$ & $0.479^{\mathrm{b}} \pm 0.059$ \\
$\mathrm{P}_{1}(1.2 \%)$ & $0.597^{\mathrm{c}} \pm 0.033$ \\
$\mathrm{P}_{2}(2.2 \%)$ & $0.544^{\mathrm{c}} \pm 0.014$ \\
$\mathrm{P}_{3}(3.2 \%)$ & $0.310^{\mathrm{a}} \pm 0.042$ \\
\hline
\end{tabular}

Note: Different superscripts in the same column indicate a significant difference $(p<0.05)$.

In this work, we hypothesize that the addition of the amino acid lysine will influence the amount of Eicosapentaenoic Acid (EPA) in catfish flesh (Pangasius sp.). This can come about as a result of the catfish's body's optimum absorption of diet components. In terms of health, a rise in Omega-3 fat components, namely EPA, plays an essential role in the development of blood cells, heart health, and blood circulation with blood circulation.

The findings of treatment $\mathrm{P} 3$ with a substitute dose of $3.2 \%$ amino acid lysine actually revealed a lower Eicosapentaenoic Acid (EPA) content than treatments $\mathrm{P} 1$ and $\mathrm{P} 2$ with extra doses of $1.2 \%$ and $2.2 \%$, respectively. This is consistent with the observation that catfish utilise more polyunsaturated fatty acids (EPA) as an energy source for growth and development. According to Nghia et al., (2007), the availability of polyunsaturated fatty acids decreases during growth and development, which permits the catfish (Pangasius sp.) in this study to use fatty acids as an energy source.

\section{Docohexaenoic Acid (DHA)}

Animals can produce docosahexaenoic acid (DHA) from linolenic acid during desaturation or elongation mechanisms (Domenichiello et al., 2015). These unsaturated fatty acids are desaturated by 6 desaturase, which produces fatty acids through a -oxidation cycle and releases Docosahexaenoic Acid (DHA) (Oboh et al., 2017).

There was a substantial variation in DHA levels in catfish flesh based on the findings of an investigation of the administration of the amino acid lysine in catfish (Pangasius sp.) diet. Table 5 shows an analysis of the Docosahexaenoic Acid (DHA) concentration in catfish flesh. In this investigation, the DHA content of catfish flesh increased at the time of administration with the least dosage of treatment P1 (1.2\%) of $0.662 \%$. The lysine concentration in the P2 treatment increased by $0.747 \%$ after it was administered. However, as compared to other lower dosage treatments, it decreased by $0.387 \%$ in P3. 
Table 5. Levels of Docosahexaenoic Acid (DHA) in catfish meat fed the amino acid lysine with different concentrations

Treatments DHA contents (gram/100gram) \pm SD

\begin{tabular}{cc}
\hline $\mathrm{P}_{0}(0 \%)$ & $0.540^{\mathrm{b}} \pm 0.048$ \\
$\mathrm{P}_{1}(1.2 \%)$ & $0.662^{\mathrm{c}} \pm 0.026$ \\
$\mathrm{P}_{2}(2.2 \%)$ & $0.747^{\mathrm{d}} \pm 0.031$ \\
$\mathrm{P}_{3}(3.2 \%)$ & $0.387^{\mathrm{a}} \pm 0.013$
\end{tabular}

Note: Different superscripts in the same column indicate a significant difference $(\mathrm{p}<0.05)$.

According to Khalida et al., (2017), the amount of fatty acids that can be absorbed by the fish body is controlled by factors such as feed quality and feed consumption. The larger the quantity that can be absorbed by the fish body if the feed ingested by fish has a high fatty acid content and is consumed in appropriate proportions. In health, the DHA content of the fish body acts as a nerve wrapping network, initiating nerve commands and delivering nerve stimulus to the brain (Dyall, 2015). DHA is also recognized to have a vital part in the maintenance of the body's metabolic activities as a component of cell membranes and nerve tissue (Calder, 2016).

Overall, our findings demonstrated a boost in EPA and DHA levels in commercial diets supplemented with the amino acid lysine, however at lower treatment dosages. This result contradicts Fitria et al., (2020)'s claim that a rise in EPA and DHA levels may be followed by a high dosage of therapy, which in this case utilizes fermented coffee skin flour in tilapia fish feed. We further assume that the variance in DHA and EPA levels can be related to a variety of variables, including the kind of fish, metabolic processes, and feed additive components.

EPA and DHA, on the other hand, play critical roles in many parts of the human body, including cell membrane stability (Lazzarin et al., 2009), anti-inflammatory (Conquer et al., 2000; Smith et al., 2011), and are reported as precursors of several metabolites related to good lipid mediators by several researchers (Serhan et al., 2008).

\section{Water quality}

Water quality is one of the variables that contribute to the success of catfish farming. Water quality is defined as water's suitable for the survival and growth of living organisms, as assessed by water quality criteria (Fira et al., 2021; Iswari et al., 2020; Putu Angga Wiradana et al., 2020). Temperature, DO, pH, and ammonia were among the water quality characteristics measured during the research $\left(\mathrm{NH}_{3}\right)$. Table 6 shows the results of observations of water quality parameters in catfish development for 30 days.

Table 6. Values of the range of water quality parameters in catfish rearing for 30 days

\begin{tabular}{ccccc}
\hline Treatments & Temperature $\left({ }^{\circ} \mathbf{C}\right)$ & DO $(\mathbf{m g} / \mathbf{l})$ & $\mathbf{p H}$ & Ammonia $(\mathbf{m g} / \mathbf{l})$ \\
\hline P0 & $27.6-28.6$ & $4.47-6.98$ & 7.0 & 0.003 \\
P1 & $27.4-28.7$ & $4.81-6.92$ & 7.0 & 0.003 \\
P2 & $27.5-28.6$ & $4.67-7.02$ & 7.0 & 0.003 \\
P3 & $27.5-28.7$ & $4.74-7.08$ & 7.0 & 0.003
\end{tabular}

Note: DO: Dissolved Oxygen

According to the data in the table above, the water temperature in the catfish rearing container for 30 days with various treatments ranged from $27.4^{\circ} \mathrm{C}$ to $28.7^{\circ} \mathrm{C}$. The dissolved 
oxygen (DO) concentration of the water in all catfish rearing containers ranges between 4.47 $\mathrm{mg} / \mathrm{L}$ and $7.08 \mathrm{mg} / \mathrm{L}$. The catfish rearing container had the same degree of acidity $(\mathrm{pH})$ of 7.0 and ammonia of $0.003 \mathrm{mg} / \mathrm{L}$ after 30 days of varied treatments.

The range of water quality in catfish rearing is within normal air quality criteria that support fish life, namely, temperatures ranging from $28-32^{\circ} \mathrm{C}$, DO levels required between 3-6 ppm, and the $\mathrm{pH}$ of catfish-tolerable waters, namely pH 5-9 (Khairuman \& Sudenda, 2002). According to Djarijah, (2001), the maximum amount of NH3 a catfish can tolerate is $1 \mathrm{ppm}$.

Temperature fluctuations can stress fish and inhibit catfish activity in the water. Fish require dissolved oxygen to perform functions such as swimming, reproduction, breathing, and growth. The $\mathrm{pH}$ value and the amount of feeding both impacts the rise in $\mathrm{NH} 3$ concentration (Riandi et al., 2021)

\section{Conclusions}

The addition of the essential amino acid lysine to the diet was able to improve the Eicosapentaenoic Acid (EPA) content of catfish flesh with P1 (1.2\%), which was $0.597 \%$. Similarly, adding the important amino acid lysine can boost the amount of Docosahexaenoic Acid (DHA) in catfish flesh. P2 treatment received the best dosage of amino acid lysine, which was $0.747 \%$, with a dose of lysine amino acid $2.2 \%$. Future study on the effect of increased EPA and DHA levels on growth rates, survival rates, cholesterol ratio content, and similar studies targeted at enhancing the productivity of catfish intake in the community is required.

\section{Acknowledgments}

The author thanks Dr. Widya Paramita L, MP, Prof. Dr. Dewa Ketut Meles, and Annur Ahadi Abdillah, M.Sc for their suggestions and input during the research. The author would like to thank Sri Gunarso from the Faculty of Pharmacy, Universitas Airlangga, who has assisted in measuring levels of EPA, DHA, and fatty acid components. Thanks to Tri Nurhajati from Animal Feed Laboratory, Faculty of Veterinary Medicine, Universitas Airlangga for the technical analysis of feed proximate. Thanks to Dr. I Dewa Gede H.W from the Integrated Laboratory, Health Polytechnic of the Ministry of Health Surabaya for his assistance in analyzing the lysine content in the treatment of this study.

\section{References}

Alagawany, M., Elnesr, S. S., Farag, M. R., Abd El-Hack, M. E., Khafaga, A. F., Taha, A. E., Tiwari, R., Yatoo, M. I., Bhatt, P., Khurana, S. K., ... \& Dhama, K. (2019). Omega-3 and Omega-6 Fatty Acids in Poultry Nutrition: Effect on Production Performance and Health. Animals, 9(8), 573. https://doi.org/10.3390/ani9080573

Borum, P. R. (2020). Carnitine. In Present Knowledge in Nutrition (pp. 551-559). Elsevier. https://doi.org/10.1016/B978-0323-66162-1.00033-0

Brautaset, T., \& Ellingsen, T. E. (2011). Lysine. In Comprehensive Biotechnology ( $\mathrm{pp}$. 541-554). Elsevier. https://doi.org/10.1016/B978-0-08088504-9.00220-8

Calder, P. C. (2016). Docosahexaenoic Acid. Annals of Nutrition and Metabolism, 69(Suppl. 1), 8-21. https://doi.org/10.1159/000448262

Conquer, J. A., Tierney, M. C., Zecevic, J., Bettger, W. J., \& Fisher, R. H. (2000). Fatty acid analysis of blood plasma of patients with alzheimer's disease, other types of dementia, and cognitive impairment. Lipids, 35(12), 1305-1312. https://doi.org/10.1007/s11745-000-06463

Dale, N. M. (2001). Nutrient Value of Catfish Meal. Journal of Applied Poultry Research, 10(3), 252-254. https://doi.org/10.1093/japr/10.3.252

Djarijah, A. (2001). Budidaya Ikan Patin. Kanisius.

Domenichiello, A. F., Kitson, A. P., \& Bazinet, R. P. (2015). Is docosahexaenoic acid 
synthesis from $\alpha$-linolenic acid sufficient to supply the adult brain? Progress in Lipid Research, 59, 54-66. https://doi.org/10.1016/j.plipres.2015.04. 002

Dyall, S. C. (2015). Long-chain omega-3 fatty acids and the brain: a review of the independent and shared effects of EPA, DPA and DHA. Frontiers in Aging Neuroscience, 7. https://doi.org/10.3389/fnagi.2015.00052

FAO. (2013). FAO Yearbook: Fisheries and Aquaculture Statistics 2011 (Production from Aquaculture by Country and by Species).

Fira, D., Wiradana, P., Ansori, A., Susilo, R. J. K., \& Sabdoningrum, E. (2021). Ectoparasite inventorisation of nilem fish (Osteochilus hasselti) fingerlings cultured on ponds in Sukabumi, West Java, Indonesia. Iraqi Journal of Veterinary Sciences, 35(3), 605-609. https://doi.org/10.33899/ijvs.2020.127031 .1440

Fitria, P. D., Amin, M., Lokapirnasari, W. P., \& Lamid, M. (2020). Supplementation of fermented coffee-peel flour to increase high-density lipoprotein (HDL) cholesterol, docosahexaenoic acids (DHA) and eicosapentaenoic acids (EPA) deposition in tilapia fillet. Biocatalysis and Agricultural Biotechnology, 24(February), 101502. https://doi.org/10.1016/j.bcab.2020.10150 2

Gammone, M. A., Riccioni, G., Parrinello, G., \& D'orazio, N. (2019). Omega-3 polyunsaturated fatty acids: Benefits and endpoints in sport. Nutrients, 11(1), 1-16. https://doi.org/10.3390/nu11010046

Girsang, V., Reveny, J., \& Nainggolan, M. (2020). Isolation and Characterization Collagen of Patin Fish Skin (Pangasius Sp.). Asian Journal of Pharmaceutical Research and Development, 8(1), 47-51. https://doi.org/10.22270/ajprd.v8i1.661
Iswari, R. D. S., Wiradana, P. A., Kusdarwati, R., Suwanti, L. T., Kurniawan, S. B., \& Abdullah, S. R. S. (2020). Prevalence and Intensity Level of Ectoparasites on Nile Tilapia ( Oreochromis niloticus ) Cultured in Biofloc Systems at Sukabumi Regency , West Java, Indonesia. Technology Reports of Kansai University, 62(December), 5753-5763.

Khairuman, \& Sudenda, D. (2002). Budidaya Ikan Mas Secara Intensif. Agro Media Pustaka.

Khalida, A., Agustono, A., \& Paramita, W. (2017). Penambahan Lisin pada Pakan Komersial terhadap Retensi Protein dan Retensi Energi Ikan Bawal Air Tawar (Colossoma macropomum) [Lysine Addition on Commercial Feed to the Protein Retention and Energy Retention Colossoma macropomum]. Jurnal Ilmiah Perikanan Dan Kelautan, 9(2), 98. https://doi.org/10.20473/jipk.v9i2.7637

KKP. (2010). Festival Raya Lele Nusantara.

Kwasek, K., Thorne-Lyman, A. L., \& Phillips, M. (2020). Can human nutrition be improved through better fish feeding practices? a review paper. Critical Reviews in Food Science and Nutrition, 60(22), 3822-3835. https://doi.org/10.1080/10408398.2019.1 708698

Lakshmi, B., Syed, S., \& Buddolla, V. (2019). Current Advances in the Protection of Viral Diseases in Aquaculture With Special Reference to Vaccination. In Recent Developments in Applied Microbiology and Biochemistry (pp. 127146).

Elsevier. https://doi.org/10.1016/B978-0-12816328-3.00010-6

Lazzarin, N., Vaquero, E., Exacoustos, C., Bertonotti, E., Romanini, M. E., \& Arduini, D. (2009). Low-dose aspirin and omega-3 fatty acids improve uterine artery blood flow velocity in women with 
recurrent miscarriage due to impaired uterine perfusion. Fertility and Sterility, 92(1), 296-300. https://doi.org/10.1016/j.fertnstert.2008.0 5.045

Lestari, D. U., Sumardianto, S., \& Purnamayati, L. (2020). The Characteristics of Striped Catfish Oil (Pangasius hypophthalmus) Extracted by Dry Rendering Method at Different Temperatures. Caraka Tani: Journal of Sustainable Agriculture, 35(1), 66.

https://doi.org/10.20961/carakatani.v35i1. 31604

Longo, N., Frigeni, M., \& Pasquali, M. (2016). Carnitine transport and fatty acid oxidation. Biochimica et Biophysica Acta (BBA) - Molecular Cell Research, 1863(10), 2422-2435. https://doi.org/10.1016/j.bbamcr.2016.01. 023

Nghia, T. T., Wille, M., Vandendriessche, S., Vinh, Q. T., \& Sorgeloos, P. (2007). Influence of highly unsaturated fatty acids in live food on larviculture of mud crab Scylla paramamosain (Estampador 1949). Aquaculture Research, 38(14), 1512 1528. https://doi.org/10.1111/j.13652109.2007.01815.x

Nirmala, K., Lesmono, D. P., \& Djokosetiyanto, D. (2007). Effect of Salinity Adaptation Technique on Survival and Growth Rate of Patin Catfish, Pangasius sp. Jurnal Akuakultur Indonesia, 4(1), 25. https://doi.org/10.19027/jai.4.25-30

Oboh, A., Kabeya, N., Carmona-Antoñanzas, G., Castro, L. F. C., Dick, J. R., Tocher, D. R., \& Monroig, O. (2017). Two alternative pathways for docosahexaenoic acid (DHA, 22:6n-3) biosynthesis are widespread among teleost fish. Scientific Reports, $\quad 7(1), \quad 3889$. https://doi.org/10.1038/s41598-01704288-2

Pizzini, A., Lunger, L., Demetz, E., Hilbe, R., Weiss, G., Ebenbichler, C., \& Tancevski,
I. (2017). The Role of Omega-3 Fatty Acids in Reverse Cholesterol Transport: A Review. Nutrients, 9(10), 1099. https://doi.org/10.3390/nu9101099

Pramudya, D. R. (2014). Pengaruh Pemberian Enzim Pada Pakan Komersil Terhadap Pertumbuhan Dan Rasio Konversi Pakan (FCR) Pada Ikan Patin (Pangasius sp.) [Universitas Airlangga]. http://repository.unair.ac.id/id/eprint/2634 7

Rario. (2015). Fish Fillet Catfish Processing Technology from Central Kalimantan, Indonesia. IOSR Journal of Environmental Science Ver. II, 9(5), 2319-2399. https://doi.org/10.9790/2402-09521825

Riandi, M. I., Susilo, R. J. K., Sani, M. D., Maharani, A. Y., Soegianto, A., Putranto, T. W. C., \& Wiradana, P. A. (2021). Surveillance Of Vibrio and Blue-Green Algae In Intensive System Of Pacific White Shrimp (Litopenaeus Vannamei) In Situbondo Regency, East Java , Indonesia. Poll Res, 40(2), 611-616.

Scollan, N. D., Price, E. M., Morgan, S. A., Huws, S. A., \& Shingfield, K. J. (2017). Can we improve the nutritional quality of meat? Proceedings of the Nutrition Society, 76(4), 603-618. https://doi.org/10.1017/S0029665117001 112

Serhan, C. N., Chiang, N., \& Van Dyke, T. E. (2008). Resolving inflammation: dual anti-inflammatory and pro-resolution lipid mediators. Nature Reviews Immunology, $8(5)$, 349-361. https://doi.org/10.1038/nri2294

Smith, G. I., Atherton, P., Reeds, D. N., Mohammed, B. S., Rankin, D., Rennie, M. J., \& Mittendorfer, B. (2011). Dietary omega-3 fatty acid supplementation increases the rate of muscle protein synthesis in older adults: a randomized controlled trial. The American Journal of Clinical Nutrition, 93(2), 402-412. https://doi.org/10.3945/ajcn.110.005611 
Stoneham, T. R., Kuhn, D. D., Taylor, D. P., Neilson, A. P., Smith, S. A., Gatlin, D. M., Chu, H. S. S., \& O'Keefe, S. F. (2018). Production of omega-3 enriched tilapia through the dietary use of algae meal or fish oil: Improved nutrient value of fillet and offal. PLOS ONE, 13(4), e0194241. https://doi.org/10.1371/journal.pone.0194 241

Syukur, A. G., Nurhayati, T., \& Nurilmala, M. (2014). Karakteristik Filet Ikan Patin (Pangasius sp.) Dalam Negeri dan Impor [IPB University]. http://repository.ipb.ac.id/handle/1234567 $89 / 71398$

Tran, N., Rodriguez, U.-P., Chan, C. Y., Phillips, M. J., Mohan, C. V., Henriksson, P. J. G., Koeshendrajana, S., Suri, S., \& Hall, S. (2017). Indonesian aquaculture futures: An analysis of fish supply and demand in Indonesia to 2030 and role of aquaculture using the AsiaFish model. Marine Policy, 79 , 25-32. https://doi.org/10.1016/j.marpol.2017.02. 002

Wiradana, P. A., Mahasri, G., Sari, R. E. R., Marwiyah, U. C., \& Prihadhana, R. (2019). Identification of white spot syndrome virus (WSSV) in pacific white shrimps (Litopenaeus vannamei) from ponds postexposure to immunogenic membrane proteins (Zoothamnium penaei). IOP Conference Series: Earth and Environmental Science, 236(1). https://doi.org/10.1088/17551315/236/1/012085

Wiradana, Putu Angga, Anjani, S., Yusup, D. S., Wiryatno, J., Melianawati, R., Naw, S. W., Nege, A. S., \& Soegianto, A. (2020). Copepod growth populations ( Acartia sp .) in outdoor mass culture tanks: Exploring natural feed potentials for sustainable aquaculture. 26(3), 1382 1387.

Wiradana, Putu Angga, Darmayasa, I. B. G., \& Wiratmin, N. I. (2018). The Test of Saccharomyces sp. Potential Filtrate to Inhibit The Growth of Aspergillus flavus FNCC6109 Broiler Chicken Concentrate Feed Model. Proceedings of the 2nd International Conference Postgraduate School, 532-536. https://doi.org/10.5220/00075464053205 36

Xie, F., Zeng, W., Zhou, Q., Wang, H., Wang, T., Zheng, C., \& Wang, Y. (2012). Dietary lysine requirement of juvenile Pacific white shrimp, Litopenaeus vannamei. Aquaculture, 358-359, 116-121. https://doi.org/10.1016/j.aquaculture.2012 .06 .027 